\title{
THE HYDROLYSIS OF POLYESTER-ETHER HOMOLOGS BY AN ALKALI
}

\author{
By Yoshitake Yamamoto, Osamu Sangen and Hidehiko Nakano \\ (Department of Applied Chemistry, Himeji Institute of Technology, \\ Shosha-2167, Himeji 671-22, Japan)
}

\section{Synopsis}

The rate of hydrolysis of aromatic polyester-ether homologs in an aqueous caustic soda solution was investigated at temperatures of $60^{\circ} \mathrm{C}$ to $90^{\circ} \mathrm{C}$, and the activation energy for the reaction was determined. The results indicate that the polyester-ether homologs have higher alkali resistances than poly(ethylene terephthalate). The activation energy for hydrolysis of poly(ethylene 1,2-diphenoxyethane- $p, p^{\prime}$-dicarboxylate) [B type polyester-ether] was estimated as high as $22.6 \mathrm{kcal} / \mathrm{mole}$.

\section{Introduction}

The hydrolysis of polyesters in an aqueous alkali solution is a heterogeneous reaction. Horio et al. ${ }^{1)}$ examined the extent of alkali-resistance of polyester-ethers ( $B$ type and $V$ type polymers), where powdered polymers were used and the activation energy for hydrolysis was not determined. Farrow et al. ${ }^{2)}$ pointed out a complexity of the hydrolytic reaction of PET by organic amines. Kuriyama et al. $^{3)}$ investigated the hydrolysis of fibrous samples of polyesters prepared from $\beta$-hydroxy aromatic acid and of PET in an aqueous caustic soda solution, indicating that the rate of hydrolysis could be estimated by following the weight loss of the fibers as a function of time and that the rate constant of the reaction was mainly influenced by the specimen shape since the hydrolysis took place on the fiber surface.

In the present study, the rate of hydrolysis of aromatic polyester-ether homologs, shown in Figure 1, in an aqueous caustic soda solution was measured at temperatures of $60^{\circ} \mathrm{C}$ to $90^{\circ} \mathrm{C}$, and the activation energy for the reaction was determined. The result will be compared with those of poly(ethylene terephthalate) [PET].

A modification of the Kuriyama's method was made here in order to avoid the specimen shape effect on the rate constant. Therefore, we used an amorphous thin film to determine the rate of hydrolysis, because the surface area is assumed as constant throughout the hydrolytic reaction.

Thus the rate constant of hydrolysis, $K_{p}$, is calculated using the following equation (1) and (2).

$$
\begin{aligned}
& -\mathrm{d} x / \mathrm{d} t=K_{p} \cdot S \\
& K_{p} \cdot t=(A-x) / S
\end{aligned}
$$

where, $S\left[\mathrm{~cm}^{2}\right]$ is the surface area of the sample film, $A[\mathrm{gr}]$ is the initial weight of the sample, and $x[\mathrm{gr}]$ is the weight of the sample remaining after time $t$. The equations are based on the assumption that the hydrolysis takes place on the surface of the sample and the resulting polyester-ether seg. ments, via the chain scission, are soluble in the solution.

\section{Experimental}

Polyester-ethers (Fig. 1) and PET were prepared by the procedures reported previously ${ }^{4,5)}$. An amorphous film with $20 \mathrm{~mm}$ in width and $0.05 \mathrm{~mm}$ in thickness was prepared by quenching from the melt and the hydrolytic reaction was carried out at several temperatures by maintaining the films in $20 \%-\mathrm{NaOH}$ aqueous solution with gentle stirring. The rate constant was estimated from the weight loss per unit area of the films at fixed time intervals. 


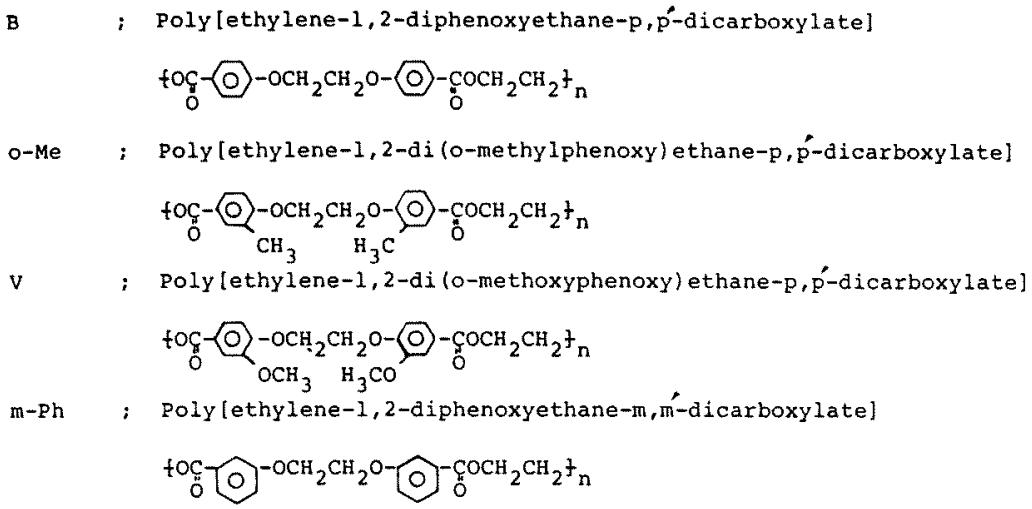

Fig. 1 Chemical structure of polyester-ether homologs.

\section{Results and Discussion}

Using the eq. (2), the temperature dependence of the weight loss per unit area of the polymer film by hydrolysis at $70^{\circ} \mathrm{C}$ is shown in Figure 2 . Linear correlations between the reaction time and the weight loss were obtained. Apparent rate constants were determined at various temperatures, as is listed in Table 1 . The activation energy for the hydrolysis was estimated from the Arrhenius plots of Figure 3 and is listed in Table 2. The activation energy, $12.8 \mathrm{kcal} / \mathrm{mole}$, for PET obtained here is close to $15.5 \mathrm{kcal} /$ mole for fibrous samples obtained by Kuriyama et al. ${ }^{3}$ )

As is evident from Table 2, the polyester-ethers other than a homolog $\mathrm{m}-\mathrm{Ph}$ gave the activation

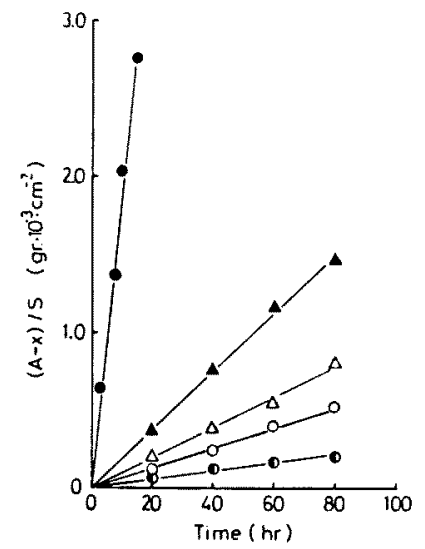

Fig. 2 The loss in quantities of polymer films by hydrolysis in an aqueous alkali at $70^{\circ} \mathrm{C}$. ( ... PET, O ... B, O ... o-Me, A ... m-Ph, $(\triangle \ldots V)$
Table 1 Rate constants of the hydrolysis of polyester-ethers and PET

\begin{tabular}{lrrrr}
\hline & \multicolumn{4}{c}{$K_{p} \times 10^{4}\left(\mathrm{gr} \cdot \mathrm{cm}^{-2} \cdot \mathrm{hr}^{-1}\right)$} \\
\cline { 2 - 5 } Polymers & $60^{\circ} \mathrm{C}$ & $70^{\circ} \mathrm{C}$ & $80^{\circ} \mathrm{C}$ & $90^{\circ} \mathrm{C}$ \\
\hline o-Me & 0.05 & 0.13 & 0.46 & 1.48 \\
B & 0.12 & 0.31 & 0.98 & 1.59 \\
V & 0.18 & 0.48 & 1.10 & 2.24 \\
m-Ph & 0.63 & 1.40 & 2.00 & 3.10 \\
PET & 6.20 & 10.54 & 17.16 & 29.20 \\
\hline
\end{tabular}

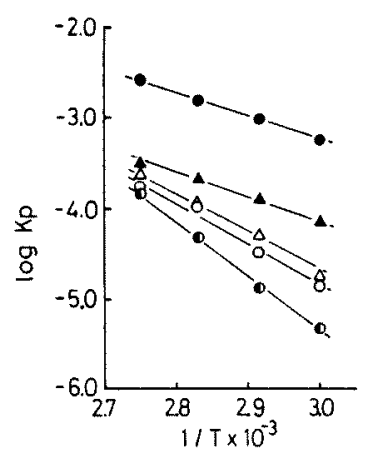

Fig. 3 Arrhenius plots of the alkaline hydrolyses of PET (O) and various polyester-ethers: $\mathrm{B}(\mathrm{O})$, o-Me (O), $\mathrm{m}-\mathrm{Ph}(\Delta)$ and $\mathrm{V}(\Delta)$.

Table 2 Activation energy of the hydrolysis

\begin{tabular}{lc}
\hline Polymers & $\begin{array}{c}\text { Activation energy } \\
\mathrm{kcal} \cdot \text { mole }^{-1}\end{array}$ \\
\hline o-Me & 27.9 \\
B & 22.6 \\
V & 20.1 \\
m-Ph & 15.1 \\
PET & 12.8 \\
\hline
\end{tabular}


energies higher than $20 \mathrm{kcal} / \mathrm{mole}$. This indicates that the polyester-ether homologs have a higher alkali resistance than PET.

Kuriyama et $\mathrm{al}^{3)}$ pointed out that the lower rate of hydrolysis of polyester from $\beta$-hydroxyethyl aromatic acid [polyester $\mathrm{A},+\mathrm{OCH}_{2} \mathrm{CH}_{2} \mathrm{O}-$ (0)- $-\mathrm{CO}-{ }_{n}$ ] than that of PET may be due to a difference in chemical constitution between the two polymers, and this can be explained by Hammett's law. ${ }^{3)}$ That is, according to the Hammett's equation $\log k=\log k_{0}+\rho \cdot \sigma$ (where, $\rho$ is the reaction constant, $\sigma$ is the substituent constant, $k_{\mathbf{0}}$ and $k$ are the rate constants of benzoic acid and benzoic acid with side substituent, respectively), $k$ for polyester $\mathrm{A}$, having the phenoxy ether linkages in the para-position on the benzene nucleus ( $\sigma=-0.25$ ), is much smaller than that for PET which has the carboxyl ester linkages $(\sigma=+0.522)$. The similar behavior for B which has the phenoxy ether linkages as polyester A can be expected.

The $\sigma$ values of the Hammett's law for the polyester-ether homologs are listed in Table 3. The order of magnitude of $K_{p}$ for the polyesterether homologs shown in Table 2 is in accord with
Table 3 Hammett substituent constants, $\sigma$

\begin{tabular}{lll}
\hline Polymers & \multicolumn{1}{c}{ Substituents } & \multicolumn{1}{c}{$\sigma$} \\
\hline $\mathrm{o}-\mathrm{Me}$ & $\mathrm{m}-\mathrm{CH}_{3}, \mathrm{p}-\mathrm{OC}_{2} \mathrm{H}_{5}$ & $-0.319^{\mathrm{a})}$ \\
B & $\mathrm{p}-\mathrm{OC}_{2} \mathrm{H}_{5}$ & -0.250 \\
$\mathrm{~V}$ & $\mathrm{~m}-\mathrm{OCH}_{3}, \mathrm{p}-\mathrm{OC}_{2} \mathrm{H}_{5}$ & $-0.135^{\mathrm{a})}$ \\
$\mathrm{m}-\mathrm{Ph}$ & $\mathrm{m}-\mathrm{OC}_{2} \mathrm{H}_{5}$ & +0.150 \\
PET & $\mathrm{p}-\mathrm{COOC}_{2} \mathrm{H}_{5}$ & +0.522 \\
\hline
\end{tabular}

a); calculated from an additivity of $\sigma$ value

our expectations based on the $\sigma$ values for the substituents.

\section{References}

1) M. Horio, R. Imamura, T. Kiyotsukuri and $T$. Takegoshi; Reports of Nihon Chemical Fiber's Laboratory, 19, 43 (1962)

2) G. Farrow, D. A. S. Ravens and I. M. Ward; Polymer, 3, 17 (1962)

3) S. Kuriyama and M. Korematsu; Sen-i Gakkaishi, 16, 110 (1960)

4) R. Imamura, T. Kiyotsukuri, Y. Yamamoto, O. Sangen and M. Horio; Sen-i Gakkaishi, 23, No. 2, 51 (1967)

5) Y. Yamamoto, O. Sangen, K. Aikawa and H. Nakano; Sen-i Gakkaishi, 39, No. 5, 220 (1983)

\section{ポリエステルエーテル同族体のアルカリ加水分解}

芳香族ポリエステルエーテル同族体のアルカリ加水分 解速度を $60^{\circ} \mathrm{C} \sim 90^{\circ} \mathrm{C}$ の温度下で測定し，加水分解の活性 化エホルギーを求めた。測定の結果，芳香族ポリエステ ルエーテル同族体がポリエチレンテレフタラートより高
姫路工業大学山本吉威, 三軒 齊, 中野英彦

い耐アルカリ性をむつととがわかった。ポリエチレンー 1,2-ジフェノキシエタンーp, p'ージカルボキシラート(B 型ポリエステルエーテル)についての加水分解の活性化工 ネルギーの值は $22.6 \mathrm{kcal} \cdot \mathrm{mole}^{-1}$ であった。 